\title{
Orthorexia Nervosa and Family Functionality in Children and Adolescents with Type 1 Diabetes Mellitus Tip 1 Diabetes Mellitusu olan Çocuk ve Ergenlerde Ortoreksiya Nervosa ve Aile İşlevselliği
}

\author{
${ }^{1}$ Tulin Fidan, ${ }^{2}$ Zerrin Orbak, ${ }^{3}$ Kezban Karabag, ${ }^{4}$ Kubra Kocak \\ ${ }^{1}$ Osmangazi University Faculty of Medicine Department of Child and adolescent Psychiatry, \\ Eskisehir, Turkey \\ ${ }^{2}$ Atatürk University Faculty of Medicine Department of Pediatric Endocrinology, Erzurum, Turkey \\ ${ }^{3}$ Erzurum Research and Training Hospital Department of Pediatrics, Erzurum, Turkey \\ ${ }^{4}$ Erenköy Psychiatric and Neurological Diseases Research and Training Hospital Department of Child \\ and adolescent Psychiatry, İstanbul
}

\begin{abstract}
Type 1 diabetes is an autoimmune disorder characterized by an absolute insülin. Deficiency (1).In this study we examine the eating attitudes of children and adolescents with Type 1 diabetes. A total of 96 child and adolescents, 48 with DM Type 1 and 48 healthy controls were included in the study. The data regarding the socio-demographic features of the child and adolescents were collected by a form and ORTHO-11 were administered. In this study, in statistical analyses $\mathrm{p}<0.05$ was considered as statistically significant for all values. In total sample, $55.2 \%$ were male and the mean age was $12.18 \pm 3.23$ years (range: 7-19 years). Of the child and adolescents with DM type I only $10.4 \%$ were having more than 3 times meal in a day and,\%52.1 were chow down while watching TV and \%62.3 were watching TV more than 2hours/ a day. We were unable to find a significant difference between eating attitudes of child and adolescents according to age and sex $(\mathrm{p}>0.05)$. We found a significant difference in the mean scores of ortorexia between two groups $(\mathrm{t}=-2.135, \mathrm{p}<0.05)$. The main treatment in DM type 1 was insulin replacement and diet.In this study only $10 \%$ children and adolescents with DM type 1 were having their diets regularly and most of them eating fast food. Also they were watching television more than 2 hours in a day and while watching TV they were chowing down. This is similar with previous reports that watching TV too much complicate making regular diet but healthy eating behavior was found better than controls.
\end{abstract}

Keywords: Orthorexia nervosa, DM, family functionality, child mental health

Fidan T., Orbak Z., Karabag K., Kocak K. (2017). Orthorexia Nervosa and Family Functionality in Children and Adolescents with Type 1 Diabetes Mellitus, Osmangazi Journal of Medicine, 39(2):1-6. DOI: 10.20515/otd.308029.

Öz: Diabetes Mellitus Tip 1, insulin eksikliği ile karakterize, diyet ve sürekli insulin tedavisi gerektiren süregen, otoimmun bir hastalıktır (1). Bu çalışmada DM Tip 1 tanısı olan çocukların yemek yeme alışkanlıkları değerlendirilmiştir. AÜTF Çocuk Endokrinoloji Polikliniğinde DM tip 1 tanısıyla takip edilen 48 çocukla ve kontrol grubu olarak sağlıklı 48 çocuk bu çalışmaya dahil edilmiştir. Çocuklara yeme alışkanlıklarını sorgulayan bizim tarafımızdan hazırlanan form ve ORTO-11 ölçeği uygulanmış ve sonuçlar istatistiksel olarak SPSS 15.0 ile değerlendirilmiştir. Tüm veriler için $\mathrm{p}<0.05$ anlamlı olarak

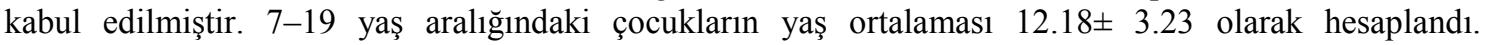
Çocukalrın \%55,2'si erkekti. Sadece \%10.4'ü günlük diyetini 3 ögünden fazla yapıyordu.\%85.4'ü fastfood tüketirken,\%52.1'i TV izlerken atıştırıyordu ve \%62.3'ü günde 2 saatten fazla TV seyrediyordu. Yaş ve cinsiyete göre beslenme alışkanlıkları arasında anlamlı farklılık bulunamadı (p>0.05). Sağlıklı yemek yeme alışkanlığının değerlendiren Orto-11 test puanları, DM tip 1 grubunda 24.30 \pm 5.98 ; kontrol grubunda 26.81 \pm 5.67 idi. Her iki grup arasındaki fark anlamlı bulundu $(\mathrm{t}=2.135, \mathrm{p}<0.05)$. DM tip 1 tanılı çocuklarda kesin tedavi insulin ve diyettir. Bu çalışmadaDM tip 1 tanılı çocukların çoğunun günlük TV izleme sürelerinin iki saatten fazla olması ve yarısının TV seyrederken atıştırmasının diyete uyumda zorluk oluşturduğu söylenebilir. Sağlıklı yemek yeme alışkanlığının değerlendiren Orto-11 test sonucuna göre DM tip 1 grubunun sağlıklı yemek yeme alışkanlığı kontrol grubuna göre daha iyi bulunmuştur. Anahtar Kelimeler: ortoreksiya nervosa, DM, aile işlevselliği, çocuk ruh sağlığı

Fidan T., Orbak Z., Karabag K., Kocak K (2017). Tip 1 Diabetes Mellitusu olan Çocuk ve Ergenlerde Ortoreksiya Nervosa ve Aile İşlevselliği, Osmangazi Tip Dergisi, 2017, 39 (2):1-6. DOI: 10.20515/otd.308029. 


\section{Introduction}

Dietary modifications are common treatment strategies for patients with chronic disorders, such as type 1 diabetes mellitus (T1DM), hyperlipidemia, and hypertension. Type 1 diabetes is an autoimmune disorder characterized by an absolute insulin deficiency. Insulin replacement and dietary regulation are the main treatment modalities for T1DM. Complications of DM include the triad of retinopathy, neuropathy, and nephropathy that are microvascular complications and specific to DM, and macrovascular disease (atherosclerosis that is nonspecific to DM but is greatly accelerated by its presence). Adolescent females with comorbid diabetes and eating disorders have significantly higher glycated hemoglobin A1c (HbA1c) compared with those without eating disorders [1]. In addition, those who suffer from co-morbid T1DM and anorexia nervosa are at a greater risk for death than those with only T1DM or only anorexia nervosa [2]. To prevent the complications, excellent metabolic control is an achievable goal.

Attempts to make people more aware of their food intakes and increase their nutritional knowledge might also have undesirable effects in subgroups of the population. During recent years, the description of a new eating disorder, orthorexia nervosa, has been proposed (3). Orthorexia nervosa (healthy eating) is "eating practices and behaviors that are consistent with improving, maintaining and/or enhancing health"(4).

An educated and motivated patient working with a multidisciplinary healthcare team can significantly reduce the risk of complications. Families are the primary context within this team. Most health beliefs and behaviors (e.g., smoking, diet, and exercise) are developed and maintained within the family [5]. Family relationships have as powerful an impact on health outcomes as biologic factors [6], and family interventions have been shown to improve health outcomes for a variety of health problems[7]. Family members, not healthcare professionals, provide most of the healthcare for patients. Outside the hospital, healthcare professionals give advice and suggestions for the acute and chronic illnesses, but the actual care is usually provided by the patient (self-care) and family members. Chronic illness requires families to adapt and change roles to provide the needed care. The aging of the population and increasing medical technology are leading to a significant increase in the prevalence of chronic illnesses and disabilities and a rise in family caregiving [8].

In this study, we examine the relationship between family functionality and eating behaviors among child and adolescents with T1DM.

\section{Material and Methods}

A total of 96 children and adolescents-48 with T1DM and 48 healthy controls-were included in this study. The study group consisted all of the children and adolescents who were admitted to Pediatric Endocrinology Outpatient Clinic at Research Hospital. Children with T1DM were routinely followed up on in endocrinology clinics every two to three months, and all of them had been receiving multiple doses of insulin treatment (intensive insulin treatment). Diabetics were excluded if they had any major medical diagnosis other illness than T1DM (e.g., epilepsy, Turner's syndrome, and thalassemia). None of the diabetics had chronic diabetic complications. An age- and gender-matched control group was selected randomly from the healthy children of two different public schools. The controls were selected from healthy children who did not have any physical illness or a history of psychiatric disorders. All the children and adolescents and their families were provided with information on the aim and nature of the study, and their informed consent was obtained.

The data regarding the socio-demographic features of the children and adolescents was collected by means of a form prepared by the researchers, who administered the Family Assessment Device (FAD) and ORTHO-11.

\section{Instruments}

\section{Sociodemographic form}

The sociodemographic information of the child and adolescents including age, sex, mother's and father's occupation and education, height, weight, eating attitudes (Having breakfast regularly? Eating fruits 
everyday. Consumption of milk, egg, meat, How many meals having in a day?, watching $\mathrm{Tv}$ ) were collected using an information form.

\section{Family Assessment Device (FAD)}

The Family Assessment Device (FAD) was developed by Epstein, Bolwin, and Bishop [9] .FAD is an instrument developed to determine the areas in which the family can and cannot fulfill its functions. FAD was obtained with the clinical implementation of the McMaster Model of Family Functioning. FAD consists of seven subscales, which are the subdimensions of the McMaster Model. Six of these subscales deal with each problem area concerning the family functioning separately, and each consists of 60 questions focusing on general functions. FAD, which can be administered to all family members over 12 years of age, consists of seven subscales: Problem Solving (PS), Communication (CO), Roles (RO), Affective Responsiveness (AR), Active Involvement (AI), Behavioral Control (BC), and General Functions (GF). The maximum score that can be obtained for each scale is 4. A high score indicates a malfunction. That is, if any of the dimensions in the subscales an average of 2.0 or above, it means family members is not functioning in a healthy way. The instrument was adapted to the Turkish culture with validity studies by Bulut [10] .

\section{ORTHO-11}

The ORTHO-11 test was used to propose a diagnostic process and to try to verify the prevalence of orthorexia. ORTHO-15 was adapted into Turkish as ORTHO-11 to evaluate orthorexia and consists of 11 items. Each item is scored on a 4-point Likert scale. Individuals were required to answer using the expressions of "always, often, sometimes, or never" to reflect how often they identified themselves with these expressions. Items that reflect an orthorexic tendency are scored as 1, and items that reflect a tendency toward normal eating behavior are scored as 4 . Only one item is reversely coded. Lower scores indicate an orthorexic inclination. The total score of ORTHO-11 is between 0 and 44 points [11] .The researchers selected only 11 items with factor loadings of 0.50 or higher for the Turkish version of the scale. Because there was no other study on the factor structure of the original scale, the results could not be compared with the results of earlier studies. The selection was also aimed at statistically strong items because orthorexia is a new concept in the literature. The Cronbach $\alpha$ coefficient, which shows the internal consistency of the scale, was found to be 0.44 for ORTHO-15 and 0.62 for ORTHO-11. Thus, the internal consistency was found to be statistically satisfactory for the Turkish language version [11]. Donini et al. (2005) found that when a score of 40 was taken as the cutoff point in ORTHO-15, the predictive validity of the scale was high and people with an orthorexic inclination could be discriminated [12]. The literature reveals no studies that examined the psychometric properties of ORTHO-11, the Turkish version of the scale. Thus, no cutoff point for ORTHO-11 test could be determined. A low score on the scale shows a higher tendency for orthorexia.

\section{Statistical analysis}

In this study, the SPSS-15.0 statistical package program was used for the statistical analyses. The categorical variables were presented in percentages, and the continuous variables were presented as mean \pm standard deviation. In the analyses where the groups were compared, chi-square was used for discrete variables. The One-Sample Kolmogorov-Smirnov Test was used to test the equality of variances. For continuous variables, if there was a normal distribution, a t-test was used; if not, then a Mann-Whitney $\mathrm{U}$ test was used. Also Pearson's moment correlation analyses was performed in the statistical evaluation of the data. $p<0.05$ was considered as statistically significant for all values.

\section{Results}

A total of 96 children and adolescents with T1DM and healthy controls having similar socio-demographic features were included in this study, there was no statistical difference between two groups $(\mathrm{p}<0.05)$ Table 1 . In the total sample, $53(55.2 \%)$ were male and the mean age was $12.18 \pm 3.23$ years (range: 7-19 years).

Of the children and adolescents with T1DM, age ranged from 7 and 19 years old, and the mean age was $12.9 \pm 3.4 ; 29(60.4 \%)$ were boys and 19 (39.6\%) were girls; $70.8 \%$ were going to primary school and $29.2 \%$ were going to high school. As regards their school 
performance, $22.9 \%$ had a low school performance, while $20.8 \%$ had an average performance, and $56.3 \%$ had a high schoollevel performance. Only $14.6 \%$ had an extended family.

The difference between the histories of psychiatric disorders in the families in both groups was not found to be significant (p>0.05) (Table 1).

Most of the children and adolescents (60.5\%) were diagnosed in the winter and spring seasons. Of the children and adolescents diagnosed with T1DM, $77.1 \%$ were under the age of 6 years old. Of the children and adolescents with DM, 60.4\% had at least two years of history. The most common complaints in the first application were frequent urination and thirst $(75.0 \%)$. The characteristics of children with T1DM are shown in Table 2.

We were unable to find a significant difference between eating attitudes of children and adolescents with T1DM and the healthy controls ( $p>0.05$ ), except for the frequency of meat consumption per week $(p<0.05)$. Eating attitudes of both groups are shown in Table 3 . We were unable to find a significant difference according to sex and age in eating attitudes in both two groups.

The mean scores of FAD subcales among T1DM and control group were respectively for solving problems $1.7 \pm 0.7 ; 1.8 \pm 4.8$, communication, $\quad 1.9 \pm 0.5 ; 1.9 \pm 0.47$, roles $1.9 \pm 0.5 ; 1.9 \pm 0.4, \quad$ affective responsiveness $1.8 \pm 0.6 ; 1.7 \pm 0.4$, active involvement $2.3 \pm 0.4 ; 2.1 \pm 0.4, \quad$ behavior control $1.9 \pm 0.3 ; 1.9 \pm 0.3$ general functions $1.6 \pm 0.5 ; 1.5 \pm 0.4$. There were no statistically significant difference in the subcales of family functionality device between the patients with T1DM and the healthy control group $(\mathrm{p}<0.05)$ (Table 4).

We found a significant difference in the mean scores of orthorexia between two groups $(\mathrm{p}<0.05)$ (Table 4). In T1DM patients, $81.3 \%$ $(n=39)$ of the children and adolescents had orthorexia scores higher than or equal to 27 , in healthy controls, only $60.4 \% \quad(n=29)$ of children and adolescents had orthorexia scores higher than or equal to 27; and difference was statistically significant $(p<0.05)$. We were unable to find a statistically significant difference according to gender in the orthorexia scores of both groups ( $>0.05$ )

\section{Conclusions}

Type 1 diabetes, formerly called juvenile diabetes, is usually first diagnosed in children, teenagers, and young adults. In this study the mean age was $12.9 \pm 3.4,70 \%$ of the children and adolescents with T1DM was pubertal and most of the them were girls $(60.4 \%)$. Age of onset of T1DM showed a bimodal distribution. The first peak was attributed to increased frequency of infections in the early school years and the second one was thought to result from pubertal stress, related to insulin antagonism of growth hormone and gonadal hormones [13]. In this study aproximately one third $(1 / 3)$ of the cases were diagnosed in winter.It was stated that T1DM cases presented generally in cold seasons because islet cells were damaged initially by viral infections and an autoimmune response was responsible for ongoing injury $[14,15]$.

In this study, only $10 \%$ of children were having their diets regularly and most of them were eating fast foods. Also, they were watching television more than two hours a day and, while watching $\mathrm{TV}$, they were overeating. This is similar with previous reports that watching TV too much complicates following a regular diet but healthy eating behaviors were found to be better for patients with T1DMPage: 4 than those of the controls [16].

Type 1 diabetes mellitus is a chronic and serious metabolic disease. Optimal management of type 1 DM requires an educated, motivated patient and a physiologic insulin regimen. It was demonstrated that for diabetes onset age between 7 to 18 years, the density of the "eating disorder" group was higher, but for the younger and older onset ages the densities were lower. Thus the development of T1DM in preadolescence or adolescence seems to place girls at risk for the subsequent development of AN or BN [17]. In our study only $60.4 \%$ were girls and all of the cases with T1DM were juvenile onset, most of them $(77.1 \%)$ first diagnosed under the age of 6 years old.

To our knowledge there is no information about the new eating disorder called 'ortorexia nervosa' among child and adolescents with 
T1DM. Orthorexia is determined as a fixation with healthy or correct eatingIt consists of a pathologic obsession for biologically pure foods, healthy foods, and foods free of pesticides and other artificial substances [3].

In our study, the frequency of orthorexia in children and adolescents with T1DM was significantly higher than that of the controls $(p<0.05)$. To the best of our knowledge, there is no report about healty eating behaviors among children and adolescents with T1DM. In previous reports, healthy eating behaviors were found to be higher among medical students, medical doctors, and nutritional students [18.19.20]. The frequency of orthorexia in these goups was higher than that in our controls but was lower than that in the T1DM group. We think that an orthorexic tendency may increase during diabetes dieting.

A review of biomedical and psychosocial literature of chronic illnesses and disabilities pointed out the sources of risks encountered by children with chronic conditions as well as protective factors that can modify risk. Male gender, low self-esteem, poor psychological health, poor school achievement, and a lower sociable temperament of the children have been found to predispose them to risks. Also, unhealthy health habits (smoking and alcohol use) have been identified as important factors. At the family level, family flexibility, adaptive coping, social integration, positive meanings ascribed to the conditions, good communication, and clear boundaries appear to be protective factors. In addition, formal and informal networks and support in the community have been found to be associated with good developmental outcomes for chronically ill subjects [21]. Physiologic studies have shown that conflict and criticism among family members can have negative influences on diabetes control [22] .

In this study in the T1DM group, the functionality of families was found to be better than in the healthy control group. Of the children and adolescents in the T1DM group, $60.0 \%$ were female and approximately $76.1 \%$ of these were performing average or well in school. they were also following up at the Pediatric Endocrinology Outpatient Clinic and were properly informed about the treatments and complications of DM.

In our study, the frequency of orthorexia in children and adolescents with T1DM was significantly higher than that of controls, though the mean FAD scores were not significantly different. This situation could be related to regular and intensive diabetes dieting.

In child and adolescents with T1DM, problematic eating behaviors and symptoms should be assessed routinely. When an eating disorder is detected, diabetes management needs to be adapted, and child psychiatrists should be included in the multidisciplinary team.

\section{REFERENCES}

1. Jones JM, Lawson ML, Daneman D, Olmsted MP, Rodin G. Eating disorders in adolescent females with and without type 1 diabetes: cross sectional study. Br Med J 2000;320: 1563-6.

2. Nielsen S, Emborg C, Molbak AG. Mortality in concurrent type 1 diabetes and anorexia nervosa. Diabetes Care 2002; 25: 309-12.

3. Bratman S \& Knight D (2000) Health Food Junkies: Orthorexia Nervosa - Overcoming the Obsession with Healthful Eating. New York: Broadway Books.

4. Taylor, JP, Evers S, McKenna M. Jul-Aug. Determinants of healthy eating in children and youth. Can J Public Health 2005; 96 Suppl 3:20-6, 22-9.

5. Doherty WA, Campbell TL. Families and health. Beverly Hills USA: Sage, 1988.
6. House JS, Landis KR, Umberson D. Social relationships and health. Science 1988; 241(4865):540-5.

7. Campbell TL, Patterson JM. The effectiveness of family interventionsin the treatment of physical illness. J Marital Fam Ther 1995; 21(4):545-83.

8. Smith C K, Sheehan J P, Ulchaker M M. Diabetes mellitus. In Taylor RB, editor. Taylor's Diagnostic and Therapeutic Challenges A handbook. New York USA: Springer, 2005. p. 202-229.

9. Epstein NB, Bolwin LM, Bishop DS. The Mc Master Family Assesment Device. J Marital Fam Ther 1983; 9(2): 171-80.

10. Bulut I. The Manuel of Family Assessment Device. Ankara Turkey: Özgüzeliş Matbaası, 1990.

11. Arusoğlu G, Kabakci E, Köksal G. Orthorexia nervosa and adaptation of ortho-11 into Turkish. Turk Psikiyatri Derg 2008; 19(3): 283-91. 
12. Donini LM,, Marsili D, Graziani MP, Imbriale M, Cannella C: Orthorexia nervosa: validation of a diagnosis questionnaire. Eat Weight Disord 2005; 10:28-32.

13. Maahs DM, West NA, Lawrence JM, Mayer-Davis EJ. Epidemiology of type 1 diabetes. Endocrinol Metab Clin North Am. 2010;39:481-497.*14. Mooney JA, Helms PJ, Jolliffe IT.

14. Seasonality of type 1 diabetes mellitus in children and its modification by weekends and holidays: retrospective observational study. Arch Dis Child. 2004;89:970-973.

15. Kalliora MI, Vazeou A, Delis D, Bozas E, Thymelli I, Bartsocas CS. Seasonal variation of type 1 diabetes mellitus diagnosis in Greek children. Hormones (Athens) 2011;10:67-71.

16. Kuriyan R, Bhat S, Thomas T, Vaz M,Kurpad A V Television viewing and sleep are associated with overweight among urban and semi-urban South Indian children Nutrition Journal 2007; 6:25

17. Pinhas-Hamiel O, Hamiel U, Levy-Shraga Y.Eating disorders in adolescents with type 1 diabetes:
Challenges in diagnosis and treatment. World $\mathbf{J}$ Diabetes. 2015 Apr 15;6(3):517-26.

18. Fidan T, Ertekin V, Işikay S, Kırpınar I. Prevalence of orthorexia among medical students in Erzurum, Turkey. Comprehensive Psychiatry 2010; 51: 4954.

19. Bağci Bosi T, Camur D, Güler C. Prevalence of orthorexia nervosa in resident medical doctors in the faculty of medicine (Ankara, Turkey). Appetite 2007; 49(3): 661-6.

20. Korinth A, Schiess S, Westenhoefer J. Eating behaviour and eating disorders in students of nutrition sciences Public Health Nutrition 2009; 13(1):32-7.

21. Patterson J, Blum RW. Risk and resilience among children and youth with disabilities. Archives of Pediatrics and Adolescent Medicine 1996; 150:692-8.

22. Williams LB, Laffel LMB, Hood KK. Diabetesspecific family conflict and psychological distress in paediatric Type 1 diabetes Diabet. Med. 2009; 26: $908-14$. 